Cadernos do IL $\odot$ Cadernos do IL e Cadernos do IL e Cadernos do IL e Cadernos do IL e Cadernos do IL

\title{
APRESENTAÇÃO DO NÚMERO 42 DOS CADERNOS DO IL: A DIVERSIDADE DOS ESTUDOS LINGUÍSTICOS
}

Assim manifesta-se Roman Jakobson, em seu célebre texto Deux aspects du langage et deux types d'aphasie, publicado em seus Essais de linguistique générale em 1963: (1969): “a lingüística interessa-se pela linguagem em todos os seus aspectos - pela linguagem em ato, pela linguagem em evolução, pela linguagem em estado nascente, pela linguagem em dissolução" (p. 43). Nada poderia ser atual, no campo dos estudos da linguagem, que essa consideração do grande Jakobson.

E este número da revista Cadernos do IL comprova a amplitude de interesses da linguística defendida por Jakobson. Ele é dedicado aos Estudos da Linguagem e enfoca distintos temas de pesquisa em diferentes perspectivas teóricas. Trata-se de um dossiê que representa a diversidade da pesquisa em linguagem feita por alunos e professores em centros de excelência no Brasil.

Espera-se, com este Cadernos do IL, ampliar o debate em torno das relações entre as diferentes áreas dos estudos da linguagem e estendê-lo a outras áreas que tomam a linguagem como centro de interesse

O leitor encontrará, a seguir, artigos que versam sobre inúmeros assuntos, por exemplo:

a) os trabalhos sobre os fundamentos epistemológicos da linguística geral e de teorias linguísticas - Saussure e o Estruturalismo; Emile Benveniste, leitor de Saussure; A variação no sistema saussuriano da língua; Linguística como farol das ciências humanas; Em busca do Espaço perdido: a noção de espaço na teoria da enunciação de Benveniste;

b) as discussões em torno de aspectos aplicados das ciências da linguagem: A investigação etnográfica na sala de aula de segunda língua/língua estrangeira; $O$ Bilhete Orientador: Um gênero discursivo em favor da avaliação de textos na aula de línguas; Ensino de Latim - Discussão e Propostas, Política e planificação linguísticas de difusão internacional do português - um breve panorama; Breve reflexão acerca da escrita: a natureza das segmentações não convencionais; Uma compreensão do pretérito imperfeito do subjuntivo pelo viés da temporalidade e da modalidade.

c) os artigos em torno das relações entre diferentes áreas no interior dos estudos linguísticos: Construção de programa de disciplina de língua inglesa para o curso de graduação em letras; Terminologia e Valor Linguístico; Terminologia e o princípio da univocidade: análise qualitativa de unidades terminológicas; Análise de uma resenha midiática sob o ponto de vista da esquematização; O lugar da Práxis na $A D$;

d) as pesquisas em torno dos aspectos da aquisição e distúrbios de linguagem: Os efeitos da fala da criança: a escuta do sintoma na clínica de linguagem; $O$ distúrbio de linguagem sob uma perspectiva enunciativa; $A$ Teoria da 
Cadernos do IL o Cadernos do IL o Cadernos do IL e Cadernos do IL o Cadernos do IL o Cadernos do IL

Argumentação na Língua e a tradução interpretação da Libras;

e) os trabalhos sobre semântica e pragmática: Contribuições de Grice para o Estudo da Metáfora; Representação léxico-semântica de verbos monoargumentais;

f) as investigações sobre a variação linguística em dois campos fonologia e pragmática: A realização variável da vibrante simples em lugar de múltipla no português falado em Flores da Cunha (RS): Mudanças Sociais e Linguísticas e Aspectos pragmáticos da negação sentencial;

Como é fácil perceber, diversidade é a palavra de ordem atualmente nos estudos da linguagem. E é bom que seja assim, pois dela, certamente, depende a inovação da área sem que se perca de vista o que o tempo já nos ensinou.

Eduardo Correa Soares,

Marlene Lopes Teixeira

Valdir do Nascimento Flores

Porto Alegre, 2012. 